\title{
Desire for a Child in Rural Area of Bangladesh: A Logistic Regression Analysis
}

\author{
${ }^{1}$ Md. Rafiqul Islam and ${ }^{2} \mathrm{Md}$. Mahfuzar Rahman \\ ${ }^{1}$ Associate Professor ${ }^{2}$ Research Fellow \\ Department of Population Science \& Human Resource Development \\ University of Rajshahi, Rajshahi-6205, Bangladesh.
}

\begin{abstract}
The main focus of this study is to draw attention to some demographic, socio-cultural and economic, and programmatic factors, which are affecting the desire for a child in rural area of Bangladesh. The study shows that about $40 \%$ of the rural women aged $10-49$ years desired for a child. Applying logistic regression model with $\mathrm{R}^{2}$ and correct classification rate for checking the quality of fit on Bangladesh Demographic and health Survey (BDHS) 2004 data, the findings indicate that for achieving the replacement level fertility, the family planning program should be strengthened among the ever-married women under age 30 years. The probability of desire for an additional child is significantly higher in Chittagong and Sylhet divisions. It has also been clearly observed that desire for a child is higher among women having age at marriage 18+ years and also among women having higher education. Women having access to mass media especially TV have a statistically lower probability in desiring for a child than those without access. The probability of desire for an additional child is significantly lower for women who are involved to NGOs than that of the women who are not involved. Finally, the paper provides some suggestive policy measures so that the planners and implementers may take appropriate initiatives for achieving the replacement level fertility in Bangladesh.
\end{abstract}

Key words and phrases: Desire for a child, Bangladesh demographic and health survey (BDHS), Logistic regression model, Correct classification rate (CCR), Replacement level fertility, and Non government organizations (NGOs).

\section{Introduction}

Bangladesh, predominantly a rural country, located in the Northeastern part of South Asia, and covers an area of 147,570 square kilometers. It has a population of about 149 millions ( $7^{\text {th }}$ largest populous country among the world), with 84.8 $\%$ of the population living in rural areas [1]. 
When parents expect the 'baby' with their family decision as well as with the view of their surrounding economic and social constrains, is termed as demand for a child [2]. In brief, when parents desire a child considering their economic framework as well as social constraints is defined as demand for a child [3]. In a developing country like Bangladesh, it is almost compulsory that every boys and girls must marry and parent hood is a common feature immediately after marriage. It is believed that the couples that do not have any children must have some sort of physical defect, and they treat as sterile couple. Thus social status is also an important reason for demand of children [4]. Demand for more children is very much related to age, and it is also somewhat linked with health, the number of times she has been giving birth and so on. Also in cases of dead baby, how many it can be the demand cannot be stopped. Such many reasons may influence the demand [5]. From the global point of view, a woman should have children between 2.1 and 2.5. According to UN Population Report, $75 \%$ of developing countries are expected below replacement fertility by the year 2005 . Bangladesh is not excluded from the report. Bangladesh has undergone a remarkable demographic transition over the last two decades. The total fertility rate has declined from about 6.3 in 1975 to 3.3 in 1999-2000 (BDHS, 19992000). The trend of TFR in Bangladesh corresponding to the survey periods 1975-1976, 1993-1994, 1996-1997, 1999-2000 and 2004 are 6.1, 3.4, 3.3, 3.3 and 3.0 per woman respectively [6].

Striking change have been observed through asking how many children they would ideally like to have, the response was an average 4.1 children [7]. The desire for additional children declined noticeably over the past few decades. Bangladesh has remained traditional and conservative. Although the extent and rapidity of the decrease in fertility have been very impressive by international standards, the fertility decline in Bangladesh has stalled. This study is important and will be helpful to achieve replacement level fertility by identifying the impact of specific level of the variables as well as interactions of the selected variables, which are influential and significantly affect the aspiration for more children.

Therefore, the main aim and objective of this study is to identify and highlight some factors that have independent effect on rural respondents in desiring for more children as well as in fertility regulation so that the policy makers pay their attention to strengthen its family planning efforts, to accelerate the rate of fertility decline to be able to achieve replacement level fertility by the year 2015 .

\section{Sources of Data}

This study is based on the secondary analysis of the national-level data drawn from BDHS, 2004 conducting on behalf of the Government of Bangladesh by the National Institute of Population Research and Training (NIPORT) of the Ministry of Health and Family Welfare and implemented by Mitra and Associates of 
Dhaka, with funding from the USAID/Bangladesh. The sample for this analysis considered of 6330 ever-married women aged 10-49 years who lived in rural Bangladesh. The women who are declared as sterilizes, infecund, never had sex etc. are not included in this study.

\section{Methodology}

To examine the effects of selected demographic, socio-cultural and economic, and programmatic factors in desiring a child among the rural women, a logistic regression model is used. In this model, the dependent variable is assumed the value 1 if the respondents express their desire for a child or 0 if otherwise. There are mainly three categories of explanatory variables considered in this analysis. These are:

Demographic variables - Age of the respondents, administrative region, number of living children, age at marriage

Socio-cultural and economic variables - Respondents and their husband's education, current working status, access to mass media, that is, she listens to radio and watches TV at least once a week.

Programmatic variables - Religious status, currently pregnant status, involve to any of the NGOs Grameen bank (GB), Bangladesh Rural Advancement Committee (BRAC), Bangladesh Rural Development Committee (BRDB) and Association for Social Advancement (ASA)).

\section{Results and Discussion}

\subsection{Bivariate Analysis}

Although the current desire for a child is still high (41.2\%) among the rural evermarried women aged 10-49 in Bangladesh, there are significant variations and it found to be associated with different demographic, socio-cultural and economic, and programmatic characteristics. The results of the bivariate analysis are shown in Table 1.

The desire for a child among the rural ever-married women was found to be significantly associated with their age, administrative regions, education (both for respondents and their husbands), current pregnant and working status of respondents, number of living children, access to mass media, involve to any NGOs, and age at marriage.

The desire for a child is high (89.1\%) among the rural women whose age is 1519. The desire is decreasing with the increased of age. About half of the women 
of Sylhet division want a child. Both the respondents and their husband having higher education show higher desire for a child. The women having below 2 children express more desire for a child. More than half (56.9\%) of women who get married at 18 years and above age like to go for a child.

Table 1: Percentage of Ever-married Women Aged 10-49 Years Currently Desire for More Children by Selected Demographic and Socio-economic Characteristics, Bangladesh, 2004.

\begin{tabular}{|c|c|c|c|c|}
\hline $\begin{array}{l}\text { Background } \\
\text { characteristics }\end{array}$ & $\begin{array}{l}\text { Number of } \\
\text { respondents }\end{array}$ & $\begin{array}{l}\text { Percentage (\%) } \\
\text { currently } \\
\text { desire for more } \\
\text { children }\end{array}$ & $\begin{array}{c}\text { Chi-square } \\
\text { value }\end{array}$ & 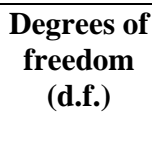 \\
\hline 1. Age: & & & $\begin{array}{c}2315.334 \\
(.000)\end{array}$ & 5 \\
\hline $15-19^{*}$ & 1160 & 89.1 & & \\
\hline $20-24$ & 1396 & 61.0 & & \\
\hline $25-29$ & 1201 & 35.6 & & \\
\hline $30-34$ & 1007 & 19.5 & & \\
\hline $35-39$ & 739 & 10.1 & & \\
\hline $40-49$ & 827 & 3.4 & & \\
\hline 2. Region: & & & $25.938(.000)$ & 5 \\
\hline Dhaka & 1227 & 40.9 & & \\
\hline Chittagong & 1119 & 44.1 & & \\
\hline Rajshahi & 1506 & 38.2 & & \\
\hline Khulna & 954 & 39.4 & & \\
\hline Barisal & 854 & 39.7 & & \\
\hline Sylhet & 670 & 48.4 & & \\
\hline $\begin{array}{l}\text { 3.Respondent's } \\
\text { education: }\end{array}$ & & & $\begin{array}{c}620.210 \\
(.000)\end{array}$ & 3 \\
\hline No education & 2433 & 26.7 & & \\
\hline Primary & 1990 & 37.9 & & \\
\hline Secondary & 1671 & 61.6 & & \\
\hline Higher secondary+ & 236 & 75.0 & & \\
\hline 4. Religion: & & & $3.240(.356)$ & 3 \\
\hline Islam & 5672 & 41.6 & & \\
\hline Christianity & 24 & 45.8 & & \\
\hline Hinduism & 622 & 37.9 & & \\
\hline Buddhist & 7 & 42.9 & & \\
\hline $\begin{array}{l}\text { 5.Currently } \\
\text { pregnant: }\end{array}$ & & & $3.702(.054)$ & 1 \\
\hline No pregnant ${ }^{\circledR}$ & 5852 & 40.9 & & \\
\hline Pregnant & 478 & 45.4 & & \\
\hline
\end{tabular}


Table 1 (continued)

\begin{tabular}{|c|c|c|c|c|}
\hline $\begin{array}{l}\text { Background } \\
\text { characteristics }\end{array}$ & $\begin{array}{l}\text { Number of } \\
\text { respondents }\end{array}$ & $\begin{array}{l}\text { Percentage (\%) } \\
\text { currently } \\
\text { desire for more } \\
\text { children }\end{array}$ & $\begin{array}{c}\text { Chi-square } \\
\text { value }\end{array}$ & $\begin{array}{l}\text { Degrees of } \\
\text { freedom } \\
\text { (d.f.) }\end{array}$ \\
\hline 6. Living Children: & & & $\begin{array}{c}3219.866 \\
(.000)\end{array}$ & 2 \\
\hline $\begin{array}{l}\text { Below } 2 \\
\text { Exactly } 2\end{array}$ & $\begin{array}{l}2053 \\
1490\end{array}$ & $\begin{array}{l}89.8 \\
34.5\end{array}$ & & \\
\hline Above 2 & 2787 & 9.0 & & \\
\hline $\begin{array}{l}\text { 7.Currently } \\
\text { working: }\end{array}$ & & & $62.876(.000)$ & 1 \\
\hline No & 5200 & 43.5 & & \\
\hline Yes & 1130 & 30.7 & & \\
\hline \multicolumn{5}{|l|}{$\begin{array}{l}\text { 8. Access to mass } \\
\text { media: }\end{array}$} \\
\hline $\begin{array}{l}\text { a. Listening to } \\
\text { radio: }\end{array}$ & & & $84.554(.000)$ & 1 \\
\hline No & 3428 & 36.0 & & \\
\hline Yes & 2902 & 47.4 & & \\
\hline b. Watching TV: & & & $77.942(.000)$ & 1 \\
\hline No & 3382 & 36.1 & & \\
\hline Yes & 2948 & 47.1 & & \\
\hline $\begin{array}{l}\text { 9. Involve to } \\
\text { NGO's: }\end{array}$ & & & $\begin{array}{c}131.524 \\
(.000)\end{array}$ & 4 \\
\hline No & 4502 & 45.7 & & \\
\hline Grameen bank (GB) & 1126 & 31.2 & & \\
\hline BRAC & 338 & 30.8 & & \\
\hline BRDB & 129 & 27.1 & & \\
\hline ASA & 235 & 26.4 & $95.222(.000)$ & 1 \\
\hline \multicolumn{5}{|l|}{ 10. Age at marriage } \\
\hline$<18$ years & 5513 & 38.9 & & \\
\hline $18+$ years & 817 & 56.9 & & \\
\hline $\begin{array}{l}\text { 11.Husband's } \\
\text { education }\end{array}$ & & & $96.493(.000)$ & 3 \\
\hline No education & 2556 & 34.5 & & \\
\hline Primary & 1758 & 43.7 & & \\
\hline Secondary & 1601 & 45.6 & & \\
\hline Higher secondary+ & 415 & 54.9 & & \\
\hline All & 6330 & 41.2 & & \\
\hline
\end{tabular}

Note: * The respondents corresponding to age group10-14 are included with age group 15-19 because of very low quantity and the value in the parenthesis indicate significance level. 


\subsection{Desire for a Child: A Logistic Regression Analysis}

Table 2 presents the estimate of logistic coefficients, standard error of estimates, wald, significant probability and the relative odds of ever-married women aged 10-49 that are calculated for each category of the categorical variables.

Since the population of the age group 25-29 constitutes a built in "Population Momentum”. Therefore, the age group 25-29 is considered as reference category. The results are statistically significant except for the age group 20-24. The women of the age group 15-19 are 2.096 times higher risk to desire for a child whereas the women of the age groups 30-34, 35-39 and 40-49 are 0.537, 0.226 and 0.083 times lower risk respectively to desire for a child than that of the age group 25-29 (reference category).

The regression coefficients of ever-married women under different geographic regions have been calculated and these are significantly associated with the desire for a child. As Dhaka is the capital of Bangladesh and the population of Dhaka division is the combination and interaction of all other divisions. Therefore, considering Dhaka division as reference category, the result indicates that the desire for a child are 1.571 and 1.983 times higher among ever-married women of rural areas for Chittagong and Sylhet divisions respectively. On the contrary, these are $0.563,0.631$ and 0.790 times lower among ever-married women of rural areas for Rajshahi, Khulna and Barisal divisions respectively.

In case of respondent's education, the result shows that higher level of education is higher desire for a child (Table 2). This may be because the women with higher education get married comparatively at higher ages. As a result, they do not like to delay to get a child. But the result (except for higher secondary+ level education) is not statistically significant.

In case of religion, except for Buddhist the remaining results are statistically significant. The results show that the rural women who believed in Christianity and Hinduism are 3.272 times higher desire and 0.623 times lower desire respectively for a child than that of rural women who believed in Islamisation (reference category).

The effect of currently pregnant women has negative significant effect in desiring for a child. The result indicates that the desire for a child is too much lower (0.099 times lower) among currently pregnant women of rural areas than that of women who are non-pregnant (Table 2). It may happen because pregnant are sure to receive a child during their pregnancy period. 
Table 2: Logistic Regression Estimates of the Odds Ratio $[\operatorname{Exp}(\beta)]$ of Background Characteristics of Ever-married Women Aged 10-49 in Rural Bangladesh.

\begin{tabular}{llllll}
\hline $\begin{array}{l}\text { Background } \\
\text { characteristics }\end{array}$ & $\begin{array}{l}\text { Coefficien } \\
\mathbf{t}(\beta)\end{array}$ & $\begin{array}{l}\text { S.E.of } \\
\text { estimates }\end{array}$ & Wald & $\begin{array}{l}\text { Significan } \\
\text { ce }\end{array}$ & $\begin{array}{l}\text { Odds } \\
\text { ratio }\end{array}$ \\
& & & & {$[\operatorname{Exp}(\beta)]$}
\end{tabular}

\begin{tabular}{|c|c|c|c|c|c|}
\hline \multicolumn{6}{|l|}{ 1. Age: } \\
\hline $25-29 ®$ & - & - & - & - & 1.000 \\
\hline $15-19$ & 0.740 & 0.153 & 23.283 & 0.000 & 2.096 \\
\hline $20-24$ & 0.140 & 0.107 & 1.712 & 0.191 & 1.151 \\
\hline $30-34$ & -0.622 & 0.123 & 25.634 & 0.000 & 0.537 \\
\hline $35-39$ & -1.486 & 0.170 & 76.659 & 0.000 & 0.226 \\
\hline $40-49$ & -2.491 & 0.238 & 109.710 & 0.000 & 0.083 \\
\hline \multicolumn{6}{|l|}{ 2. Region: } \\
\hline Dhaka® & - & - & - & - & 1.000 \\
\hline Chittagong & 0.452 & 0.128 & 12.392 & 0.000 & 1.571 \\
\hline Rajshahi & -0.574 & 0.123 & 21.921 & 0.000 & 0.563 \\
\hline Khulna & -0.460 & 0.139 & 10.986 & 0.001 & 0.631 \\
\hline Barisal & -0.235 & 0.145 & 2.640 & 0.104 & 0.790 \\
\hline Sylhet & 0.685 & 0.147 & 21.708 & 0.000 & 1.983 \\
\hline \multicolumn{6}{|l|}{$\begin{array}{l}\text { 3. Respondent's } \\
\text { education: }\end{array}$} \\
\hline No education ${ }^{\circledR}$ & - & - & - & - & 1.000 \\
\hline Primary & -0.126 & 0.103 & 1.485 & 0.223 & 0.882 \\
\hline Secondary & 0.145 & 0.126 & 1.329 & 0.249 & 1.156 \\
\hline $\begin{array}{l}\text { Higher Secondary+ } \\
\text { 4. Religion: }\end{array}$ & 0.467 & 0.261 & 3.201 & 0.074 & 1.595 \\
\hline Islam $\AA$ & - & - & - & - & 1.000 \\
\hline Christianity & 1.185 & 0.575 & 4.252 & 0.039 & 3.272 \\
\hline Hinduism & -0.473 & 0.138 & 11.779 & 0.001 & 0.623 \\
\hline $\begin{array}{l}\text { Buddhist } \\
\text { 5. Currently } \\
\text { Pregnant: }\end{array}$ & -0.789 & 1.015 & 0.604 & 0.437 & 0.454 \\
\hline No pregnant ${ }^{\circledR}$ & - & - & - & - & 1.000 \\
\hline $\begin{array}{l}\text { Pregnant } \\
\text { 6. Living Children: }\end{array}$ & -2.317 & 0.153 & 229.768 & 0.000 & 0.099 \\
\hline Exactly 2 ® & - & - & - & - & 1.000 \\
\hline Below 2 & 2.980 & 0.123 & 585.651 & 0.000 & 19.693 \\
\hline Above 2 & -1.305 & 0.103 & 160.916 & 0.000 & 0.271 \\
\hline
\end{tabular}


Table 2 (continued)

\begin{tabular}{|c|c|c|c|c|c|}
\hline $\begin{array}{l}\text { Background } \\
\text { characteristics }\end{array}$ & $\begin{array}{l}\text { Coefficien } \\
\mathbf{t}(\beta)\end{array}$ & $\begin{array}{l}\text { S.E.of } \\
\text { estimates }\end{array}$ & Wald & $\begin{array}{l}\text { Significan } \\
\text { ce }\end{array}$ & $\begin{array}{l}\text { Odds } \\
\text { ratio } \\
{[\operatorname{Exp}(\beta)]}\end{array}$ \\
\hline \multicolumn{6}{|l|}{$\begin{array}{l}\text { 7. Currently } \\
\text { working: }\end{array}$} \\
\hline No ${ }^{\circledR}$ & - & - & - & - & 1.000 \\
\hline Yes & -0.122 & 0.108 & 1.265 & 0.261 & 0.886 \\
\hline \multicolumn{6}{|l|}{$\begin{array}{l}\text { 8. Access to mass } \\
\text { media: } \\
\text { a. Listens to radio: }\end{array}$} \\
\hline No ${ }^{\circledR}$ & - & - & - & - & 1.000 \\
\hline $\begin{array}{l}\text { Yes } \\
\text { b. Watches TV: }\end{array}$ & 0.067 & 0.085 & 0.614 & 0.433 & 1.069 \\
\hline No ${ }^{\circledR}$ & - & - & - & - & 1.000 \\
\hline Yes & -0.330 & 0.089 & 13.795 & 0.000 & 0.719 \\
\hline \multicolumn{6}{|l|}{$\begin{array}{l}\text { 9. Involve to } \\
\text { NGOs: }\end{array}$} \\
\hline No ${ }^{\circledR}$ & - & - & - & - & 1.000 \\
\hline Grameen bank (GB) & -0.313 & 0.109 & 8.235 & 0.004 & 0.731 \\
\hline BRAC & -0.370 & 0.180 & 4.229 & 0.040 & 0.691 \\
\hline BRDB & -0.257 & 0.288 & 0.796 & 0.372 & 0.773 \\
\hline ASA & -0.496 & 0.224 & 4.911 & 0.027 & 0.609 \\
\hline \multicolumn{6}{|l|}{$\begin{array}{l}\text { 10. Age at } \\
\text { marriage }\end{array}$} \\
\hline$<18$ years ${ }^{\circledR}$ & - & - & - & - & 1.000 \\
\hline $18+$ years & 0.419 & 0.129 & 10.528 & 0.001 & 1.520 \\
\hline \multicolumn{6}{|l|}{$\begin{array}{l}\text { 11. Husband's } \\
\text { education }\end{array}$} \\
\hline No education ${ }^{\circledR}$ & - & - & - & - & 1.000 \\
\hline Primary & 0.047 & 0.101 & 0.215 & 0.643 & 1.048 \\
\hline Secondary & -0.210 & 0.119 & 3.135 & 0.077 & 0.811 \\
\hline Higher secondary+ & -0.081 & 0.204 & 0.157 & 0.692 & 0.922 \\
\hline Intercept & -0.019 & & & & \\
\hline -2log likelihood & 4217.447 & & & & \\
\hline Cox \& Snell R ${ }^{2}$ & 0.498 & & & & \\
\hline Nagelkerke $\mathrm{R}^{2}$ & 0.670 & & & & \\
\hline
\end{tabular}


The total number of living children is another important significant factor influencing the rural women in desiring for a child. It appears that the women, having less than two children are likely to have19.693 times higher as well as the women having more than two children are likely to have 0.271 times lower desire for a child than that of the women having exactly two children (reference category).

Working status of rural women has an effect on the desire for a child, with women who are currently working being 0.886 times less likely to desire for a child, but the effect is not statistically significant.

To show the impact of mass media in desiring for a child among women of rural areas of Bangladesh, the logistic regression coefficients of mass media (listens to radio and watches TV at least once a week) are calculated. The results shows that the women who watch TV at least once a week have 0.719 times lower desire for a child than the women who do not watch. This result also shows the highly (statistically) significant effect on desired for a child. But the result in case of radio does not show the expected result (Table 2).

The logistic regression coefficients of eligible women who are involved to any of the NGO's- GB), BRAC, BRDB and ASA are calculated. The coefficients show expected sign and the results (except corresponding to BRDP) are statistically significant. The results clearly indicate that the rural women who involved to GB, BRAC and ASA have 0.731, 0.691 and 0.609 times respectively lower desire for a child than that of the rural women who are not involved to any of the NGO's.

Age at first marriage is also significantly associated with the desire for a child among the ever-married women of rural area of Bangladesh. The result reveals that the women whose age at marriage are 18+ years expect a (1.502 times more likely) child than that of the women whose age at marriage are $<18$ years.

Husband's education has an effect on desired for a child among the rural evermarried women. The results show that the women, whose husbands have higher education, have lower desire for a child than the women whose husbands have no education. But the effect is statistically significant only for those husbands who have secondary level education.

\section{Measuring Worth of the Model}

There are various statistics that have been proposed for assessing the worth of a logistic regression model, analogous to those that are used in linear regression. Hence two of the proposed statistics are as below: 


\section{$5.1 \mathbf{R}^{2}$ in Logistic Regression}

The worth of the linear regression model can be determined by using $\mathrm{R}^{2}$, but $\mathrm{R}^{2}$ computed as in linear regression should not be used in logistic regression, at least not when the possible values of $\mathrm{Y}$ are zero and one. Therefore, Nagelkerke (1991) suggests $\bar{R}^{2}$ to be used. For the given fitted model, the Cox and Snell $\mathrm{R}^{2}=0.498$ and Nagelkerke $\bar{R}^{2}=0.670$. It is common in practice that when the value of $\bar{R}^{2}$ exceeds 0.5 , the data fit the binary regression model well. Therefore, the given logistic model can be used for the significance prediction in desiring for a child in rural Bangladesh.

\subsection{Correct Classification Rate (CCR)}

If the object is to predict whether a subject will or will not have the attribute of interest, a more meaningful measure of the worth of the model would be the percentage of subjects in the data set that classified correctly. Accordingly, the correct classification rate (CCR) is used as a measure of the fit of the model. In order to find the CCR, the Table 3 and Table 4 have to be considered.

Table 3: Observed Classification Table a, b

\begin{tabular}{|c|c|c|c|c|}
\hline \multirow{2}{*}{\multicolumn{2}{|c|}{ Desire for a child }} & \multicolumn{2}{|c|}{ Predicted } & \multirow{2}{*}{$\begin{array}{c}\text { Percentage } \\
\text { correct }\end{array}$} \\
\hline & & No & Yes & \\
\hline \multirow{3}{*}{ Observed } & No & 3717 & 0 & 100 \\
\hline & Yes & 2606 & 0 & 0 \\
\hline & $\begin{array}{c}\text { Overall } \\
\text { percentage }\end{array}$ & & & 58.8 \\
\hline
\end{tabular}

a. Constant is included in the model

b. The cut value is 0.5

Table 4: Predicted Classification Table ${ }^{\mathrm{a}}$

\begin{tabular}{|c|c|c|c|c|}
\hline \multirow{2}{*}{\multicolumn{2}{|c|}{ Desire for a child }} & \multicolumn{2}{|c|}{ Predicted } & \multirow{2}{*}{$\begin{array}{l}\text { Percentage } \\
\text { correct }\end{array}$} \\
\hline & & No & Yes & \\
\hline \multirow{3}{*}{ Observed } & No & 3401 & 316 & 91.5 \\
\hline & Yes & 575 & 2031 & 77.9 \\
\hline & $\begin{array}{l}\text { Overall } \\
\text { percentage }\end{array}$ & & & 85.9 \\
\hline
\end{tabular}

a. The cut value is 0.5 
If the threshold or cut value is to be considered as 0.5 then from Table 4 , it is observed that CCR=85.9. A model that affords better classification should be judged superior by a goodness-of-fit test. That is, a higher proportion of CCR indicates that the used logistic model is working well.

\section{Conclusion and Recommendations}

The study indicates that the desire for a child decreases as increase of age of the rural women and it is remarkable among the women under age 30 years. Chittagong and Sylhet divisions have higher desire for a child than any other divisions in rural Bangladesh. In case of non-working or housewives, the desire for a child is higher as compared to working women. The study also reveals that mass media (listens to radio and watches TV at least once a week) plays a vital role to reduce the desire for a child. The results of logistic regression analysis show that age of the respondents, administrative regions, current status of pregnancy, number of living children, watches TV at least once a week, involve to any NGOs, and age at marriage have statistically significant effect on desired for a child among rural women.

Effective policies and recommendations are needed to accelerate the rate of fertility decline in rural areas. The specific recommendations are as follows:

i. The family planning program services as well as adult education should be strengthened among rural ever-married women under age 30 and also in rural areas of Chittagong and Sylhet divisions.

ii. In order to reduce the higher desire for a child among non-working or housewives, female empowerment as well as women's socioeconomic status should be enhanced through proper education and employment.

iii. The women of the rural areas should be made aware of the positive impact of small family norm. These could be done by creating awareness through mass media campaigns such as TVs, radios, billboards etc. as well as compulsorily attaching the family planning program to the traditional activities of the NGOs. 


\section{References}

1. Population Reference Bureau (PRB): World Population Data Sheet. 1875 Connecticut Ave. NW, Washington, DC 20009 (2007).

2. Schultz, T. W.: The Value of Children: An Economic Perspective. Journal of Political Economy. Vol. 81, No. 2 (1972).

3. Lakshmanasamy, T.: Demand for Children among Rural Families: Children as a Consumption Utility. The Journal of Family Welfare. Vol. 37 (4), 3-12 (1991).

4. Bhende, A., \& Kanitkar, T.: Principles of Population Studies, Himalaya Publishing House (1997).

5. Raj, H.: Fundamentals of Demography, With Special Reference to India, Population Studies, Surjeet Publication, India (2000).

6. Mitra, S. N., Sabir, A. A., Saha, T. \& Kumar, S.: Bangladesh Demographic and Health Survey (BDHS), Dhaka: National Institute of Population Research and Training (NIPORT) (2004).

7. Huq, N. \& Cleland, J.: Bangladesh Fertility Survey. NIPORT, Azimpur, Dhaka, Bangladesh (1990).

8. Nagelkerke, N. J. D.: A Note on the General Definition of the Coefficient of Determination. Biometrika, 78, 691-692 (1991). 